\title{
Comparative Ecosystem Benefits of Common Urban Trees and Palms in South Florida ${ }^{1}$
}

\author{
Marguerite M. Beckford and Gary W. Knox²
}

Community trees provide many ecosystem services: improved air quality, reduced heat-island effects, cleaner stormwater runoff, and positive physical and mental health impacts. Additionally, a mature native tree has the lifetime capacity to sequester more than 3000 pounds of carbon dioxide as carbon (i-Tree 2020). Urban forestry Extension programs aimed at redressing canopy loss from urban development and promoting awareness of urban forestry benefits can play a significant role in urban reforestation and, ultimately, climate change mitigation. Ecosystem benefits of urban trees also have an economic impact on communities. In a study of a large midwestern US city, i-Tree data modeling determined that urban tree plantings contributed to saving the city roughly $\$ 6.8 \mathrm{M}$ in energy costs and increasing the city's property values by $\$ 7.1 \mathrm{M}$.

In addition to mature size, root structure, and plant hardiness zone, a tree's ecosystem benefits should also be considered when making informed decisions about tree planting choices in urban reforestation. Comparatively, broadleaf trees outperform many conifers and most palms in the ecosystem services they provide-for example, lifetime amount of carbon sequestered in pounds. The quantity of ecosystem benefits a tree provides will depend on the planting site. Planting the right tree in the right place, where spacing considerations and soil conditions can support optimal tree growth while minimizing tree maintenance costs and public safety risks, will result in the tree's capacity to contribute maximum ecosystem benefits.A comparison of some important ecosystem benefits by tree species is summarized in Table 1. The differences in annual carbon sequestration between species at the same location, with the same diameter at breast height (dbh) and sun exposure, is based on information the i-Tree data model uses to estimate the height of a tree based on species and $\mathrm{dbh}$. The data in the table indicates that based on information in the i-Tree data model, hardwood trees with taller estimated heights annually sequester more carbon.

More information about urban forestry Extension and the benefits of community trees is available at UF/IFAS Extension Treejuvenation Florida.

\section{References}

National Urban and Community Forestry Advisory Council (NUCFAC). 2015. Ten Year Urban Forestry Action Plan: 2016-2026. https://urbanforestplan.org/wp-content/ uploads/2015/11/FinalActionPlan_Complete_11_17_15.pdf

i-Tree. 2020. "MyTree Benefits Database." https://mytree. itreetools.org/\#/

1. This document is ENH1340, one of a series of the Environmental Horticulture Department, UF/IFAS Extension. Original publication date May 2021. Visit the EDIS website at https://edis.ifas.ufl.edu for the currently supported version of this publication.

2. Marguerite Beckford, EdD, Extension agent II, UF/IFAS Extension Sarasota County, Sarasota, FL; and Gary W. Knox, professor, Environmental Horticulture Department, UF/IFAS North Florida Research and Education Center, Quincy, FL; UF/IFAS Extension, Gainesville, FL 32611. 


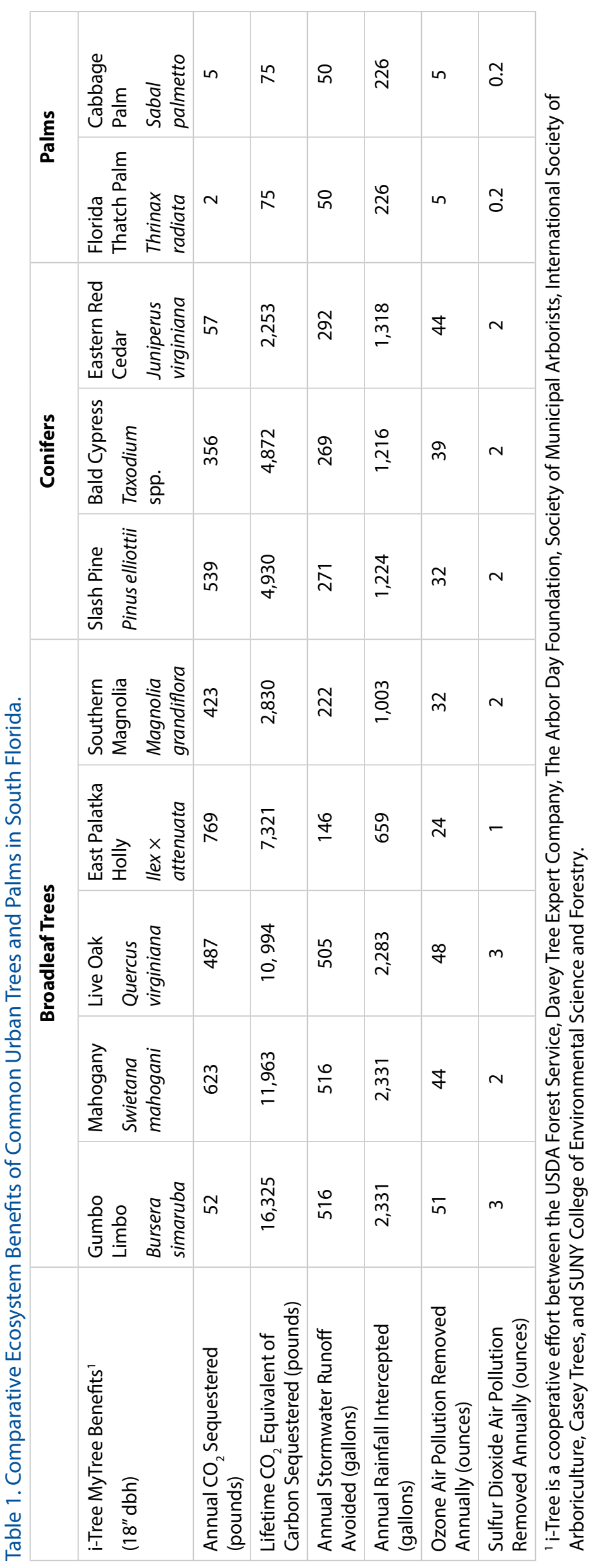

